\title{
Character Strengths and Academic Achievements of Undergraduate College Students of Guwahati, Assam
}

Sabiha Alam Choudhury ${ }^{+*}$ and Professor Indranee P. Borooah ${ }^{\breve{ }}$

\section{Abstract}

Character strengths, as conceptualised by the Values-In-Action (VIA) strengths classification system, are core characteristics of individuals that allow people to be virtuous (Seligman 2002). They are moral, intrinsically valuable, and ubiquitous traits that can be developed and enhanced. Social psychologists and sociologists consider achievements in college or university level, because of recognition and proper utilisation of the character strengths possessed by the individual students. The current study was conducted amongst 240 undergraduate college students of arts stream ( 60 males and 60 females) and science stream ( 60 males and 60 females) falling within the age group of 18-21 years, with the aim of finding out if the character strengths of the male and female undergraduate students are associated with their college academic achievements. It was found that significant correlation existed between appreciation of beauty and excellence, fairness, forgiveness, honesty, humour, kindness, love of learning and humility with the academic achievement of the students.

Keywords: Character strengths, academic achievements, students, Guwahati, Assam, India

\footnotetext{
${ }^{\dagger}$ PhD. Research Scholar, Department of Psychology, Gauhati University, Guwahati, Email:sabihaalam23@gmail.com

${ }^{*}$ Corresponding Author

İDepartment of Psychology, Gauhati University, Email:indraneephookanb@yahoo.com

(C) 2017 Choudhury and Borooah. This is an Open Access article distributed under the terms of the Creative Commons Attribution License (http://creativecommons.org/licenses/by/2.0), which permits unrestricted use, distribution, and reproduction in any medium, provided the original work is properly cited.
} 


\section{Introduction}

The key purpose of this research is to probe the character strengths and academic achievement amongst 240 undergraduate college students of two colleges-Pragjyotish College and B. Borooah College, both affiliated to Gauhati University and located in Guwahati, Assam. It is well known that the experience in the college life is one where an individual gets access to diverse opportunities to develop themselves and their skills, knowledge, attitude in better ways. It is a time when students get an opportunity to apply and understand their own unique talents and character traits, to understand what they are good at, rather than lamenting on their demerits. Students in their college and university life get an opportunity and are bestowed with the responsibility to mould up their personality and excel in their academics. Therefore, if given a proper environment, wherein the students are able to express themselves freely and get to understand their unique talents, this would lead to an enhancement of their personal wellbeing, which in turn might lead to academic achievement.

In an educational setting, academic achievement has been found to be the most important indicator of gauging the performance of the students. In most of the colleges and other educational institutions in India, examination grades are considered the most important criteria of determining the level of academic achievement. Many a times, the teachers overburdened with the excessive workload; parents overburdened with the demands of the society; the schools and colleges overburdened with the status and reputation requirement; end up assigning tasks and responsibilities to their students and children which at times turn out to be beyond their capacities and understanding. As a result, students end up considering examinations as simply an obligation to accomplish, without at times, trying to understand the main goal of their education process. Therefore it is utmost crucial, for colleges to provide an atmosphere, wherein the students are capable of undertaking the responsibility for their own actions, understand the goals of the tasks assigned to them, think creatively and critically and make full utilisation of the strengths of their character (character strengths). In this connection, it is important to take into consideration that, building up of character strengths, which is one of the critical goals of positive psychology, should be initiated in colleges, so that it would not only lead to acquiring higher grades in the present educational ventures, but also making better choices about their career. Therefore, this study was undertaken to understand the relationship between the character strengths and academic achievement of undergraduate college students. One purpose of the present investigation is to examine how character strengths of college students are related to the academic performance of college students within the geographical area of consideration. However, before understanding the concept of character strengths, it is necessary to understand the field of positive psychology.

The study begins with a discussion to the field of positive psychology, which is necessary to understand the conceptual framework of character strengths. Next, we discuss about the methodology deployed. This is followed by the results and discussion and finally, we conclude with few recommendations while outlining the limitations of the research.

\section{Positive Psychology}

For a long period, the focus of psychology has been on the treatment of mental illness. Positive psychology is a comparatively recent discipline, which takes away the focus from weakness and problems, to positive aspects and human strengths. It is a discipline, which focuses on what makes individuals, and communities as a whole, thrive and live happily. One of the pivotal goals of Positive Psychology has been the enhancement of human strengths and virtues, which have been found to be the important ingredients in human happiness and fulfilment. Positive characteristics of individuals, such as values, interests, character strengths, makes the individuals positive and 
lead to greater opportunities of positive encounters in lives and desired consequences. In fact, the science of positive psychology is the study of psychological strengths and positive emotions (Snyder and Lopez, 2007).

\section{Character Strengths}

Character strengths are important in their own right but also because they promote the individual's well-being and happiness. The Values-In-Action (VIA) strengths classification system proposed by Martin Seligman, considers that the Character strengths are the core characteristics or traits that allow individuals to be virtuous (Seligman 2002). These strengths of character are universal, internally valuable and moral characteristics of individuals, which they can develop and enhance. Six universal virtues were identified by Peterson and Seligman (2004) which were found to be valued across various cultures across the globe and those virtues were wisdom, courage, humanity, justice, temperance, and transcendence and these virtues were further subdivided into 24 character strengths. Therefore the 24 character strengths as identified by Martin Seligman are Appreciation of beauty and excellence, Creativity, open mindedness, curiosity, love of learning, perspective, bravery, persistence, judgment, zest, love, kindness, social intelligence, teamwork, fairness, leadership, forgiveness, humility, prudence, self-regulation, gratitude, hope, humour and spirituality

According to Peterson and Seligman between three to seven of the most dominant traits of people are to be considered as their signature strengths, although it was argued and often operationalized in several literature that the top five central strengths of individuals are to be considered their signature strengths (e.g. Seligman et al. 2005), and these are the strengths with which an individual identifies with, they are in fact central to their identity, and makes an individual feel contended, energetic and authentic when utilized (Peterson and Seligman 2004). It has also been found that the use of the other character strengths are also related to an individual's quality of life (Proctor et al., 2011) and leads to enhanced psychological and subjective wellbeing (Govindji and Linley, 2007).

The study on human 'character' has been of interest of people from various disciplines and fraternities since a long time and it conjures up meanings and is often found to be associated with concepts like morality, decency, honesty or integrity, etc. However, across various explanations and understandings of the term 'character', its actual meaning is often missing and people often thing that character is a construct, which is permanent and would always be the same. The word 'character' refers to those traits or characteristics, which are distinctive to an individual, which help them to make full use of their talents and flourish in the long run. In this connection it can be said that, the emphasis on human illness and weakness has a history of more than 2000 years, but efforts to identify and focus on the positive aspects and human strengths has a comparatively much recent beginning, but has appeared to grab the attention of scholars and practitioners worldwide. Therefore, it is easy to understand why we have a better understanding of human weaknesses than we do of strengths. (Snyder, 2007: 32).

It was the field of Positive Psychology, which initiated the systematic approach on emphasizing on the strengths of character and human virtues. Though there are many similarities in human strengths and talents, they are also significantly different from each other. Strength is something, which is internal, but talents are valued because of the tangible results (Peterson \& Seligman, 2004). Therefore, from the perspective of human strengths, each individual possesses the natural capacity and has the unique ability to perform and flourish (Wood et al., 2011). The VIA (Value In Action) Classification of character strengths and virtues (Peterson \& Seligman, 2004) resulted after three years of rigorous work wherein 55 scientists along with Seligman and his colleagues associated with the field of Positive Psychology, dedicated in studying character strengths in the laboratory in a scientific way. One of the important findings of numerous 
works in the field is that, each individual possesses a cluster of strengths of character and are expressive in degrees or combinations on the basis of the context or situation an individual is in, and this is what makes each individual unique.

\section{Character Strengths and Academic Achievements}

In Indian educational setup, it has been observed that the grades obtained in the academics become the destiny charters of the students and the deciding factor whether they would be able to be effective in the work front in the future. The students have to bear the baggage of expectations from their parents, teachers and society to meet the standards of academic excellence. Therefore, if there were an environment provided in the educational set up, where the students get an opportunity to understand their goals, understand the positive aspects of their character and what they are naturally good at, they would be able to achieve optimal results. According to Linley, Strengths are the things we are naturally good at and which when we apply them, produce optimal outcomes. Researches have proved that a number of character strengths, such as persistence and love of learning leads to higher academic achievement in an educational setting. Therefore, helping the students in the colleges identify and utilize their strengths of character and how certain traits can be utilised for betterment, may be instructive and informative for the undergraduate college student. Park and Peterson (2006) claimed that "Being able to put a name to what one does well is intriguing and even empowering".

In fact, many social psychologists and sociologists consider academic achievement in the college because of recognition and proper use of the unique strengths of character of the students. According to Linley, Strengths are the things we are naturally good at and which when we apply them, produce optimal outcomes. An awareness and understanding of the Character strengths and their relationship to overall wellbeing is a protective factor for the youth in their journey to adulthood.
Seligman had put forward the PERMA model, which was published in his book Flourish, in 2011. This model itself indicated that when an individual experiences more of positive emotions, engages herself/himself in meaningful activities, has positive relationships and achieves a meaning in their lives, they reach a stage of achievement of accomplishment, which ultimately leads to flourishing of the person. Therefore, when a student recognises and utilises her/his positive strengths, she/he is able to experience more of positive emotions, finds meaning in his life and the activities he/she undertakes, relates to others in meaningful ways, which ultimately leads to greater achievement in his life. Therefore, we decided to follow this model in order to examine how the students contribute (if they do contribute) to academic achievements. The following section deals with methodological issues.

\section{Methodology}

In order to investigate character strengths and academic achievements amongst undergraduate college students of Pragjyotish and B. Borooah colleges, the following research objectives were framed. They are:

- To assess the character strengths of male and female undergraduate college students of Arts and Science streams

- To explore whether character strengths is related to academic achievement.

The following hypotheses were constructed to form the basis the aforementioned objectives. They are:

- There will be a difference in the character strengths of male and female undergraduate college students.

- There will be a difference in the character strengths of arts and science undergraduate college students.

- There will be an association between character strengths and academic achievements of undergraduate college students.

The study is based on 240 undergraduate college students of arts stream (60 males and 
60 females) and science stream (60 males and 60 females) within the age group of 18-21 years, selecting 120 (60 females and 60 males) from each college. Other criteria of inclusion were-second-year undergraduate college students but limited to only those students who had cleared all papers in the first attempt in the first year. As far as the sampling techniques are concerned-multi-stage, purposive sampling technique was applied. First, all the coeducation Government colleges in Guwahati city, under the affiliation of Gauhati University, offering both Arts and Science subjects at the undergraduate level were listed. Thereafter the colleges, which gave permission to conduct the study, were selected. We however could gain permission from two colleges as mentioned above-Pragjyotish and B. Borooah colleges. From these two selected colleges, male and female students of the third semester were included who fulfilled the aforementioned inclusion criteria. The specific tools used for this research are:

- The 72-item VIA-IS (VIA-Inventory of Strengths) was used in the current study to measure the character strengths. It is a brief version of the original VIA long form consisting of 240 items. The brief form has reliability and validity scores, which is almost parallel to the original long form and has been successfully used in many researches in and across India. It is an English-language selfreport questionnaire that measures 24 widely valued character strengths.

- A record of the academic scores of the students was collected from the students themselves, as well as crosschecked with the available college records.

$2 \times 2$ factorial research design was adopted and calculated using the Mean (Mean), Standard Deviation (SD), ANOVA, Pearson's Product Moment Correlation, t-test and Tukey's Test.

\section{Results and Discussion}

Our research findings below are in line with the Martin Seligman's proposal of PERMA. The findings indicate that internal characteristics, that is, many of the character strengths (which are internal) do play an important role in enhancing academic performance of the students. It has been seen that college life for the undergraduate college students is indeed a fertile setting, where if they are given the opportunity to identify and focus on the strengths of their character, it can go a long way in improving their academic performance, and benefit them in other aspects of their life and well-being. It has been found in a study that these unique abilities and capacities is possessed by everyone, and from a strengthsbased perspective, these unique talents, that is, the character strengths can help individuals to flourish and perform their best (Wood et al., 2011).

In case of academic achievements, it was found after conducting the ANOVA, that a significant difference existed between the means of the groups when stream was taken into consideration, that is, the students in the science stream achieved higher grades as compared to the students in the arts stream and therefore, the Tukey's test was carried out to find the Honest Significant Difference between the means.

After conducting the Post-Hoc test (Tukey test), it was found that the mean difference was significant within the groups:

- The Honest Significant Difference (HSD) between Arts male and Science male was found to be 10.5333, which indicated that the Science male significantly obtained higher academic scores as compared to the Arts male.

- The HSD between Arts male and Science female was found to be 8.6917, which indicated that the Science female significantly obtained higher academic scores as compared to the Arts male.

- The HSD between Arts female and Science male was found to be 7.5483 , which indicated that the Science male significantly obtained higher academic scores as compared to the Arts female.

Therefore, it can be said after conducting the ANOVA and the post-hoc test, in the dimension 
of academic achievement, the students in the Science stream achieved higher grades as compared to the students in the Arts stream. Hussain et al in 2011 obtained similar findings when they conducted a comparative study of academic achievement of science and arts students in compulsory subject at secondary level. They found that the students of the science stream obtained higher grades as compared to the students of the arts stream irrespective of their gender.

Also, t-test was conducted and its results for academic achievements revealed a significant difference between the means of the arts and science stream students, that is, the academic achievement level of the science students is significantly higher than that of the arts students which is similar to the findings obtained after conducting the ANOVA test, and the findings is in line with the related literature as discussed above.

The t-test results for the 24 character strengths show that there is no significant difference between male and female students. The mean scores of the male students in the dimension of the character strengths is almost equal to that of the female students, hence the t-test was applied for testing the significance of mean difference, and it was not found to be significant at .01 level. Therefore the hypothesis-'There will be a difference in the character strengths of male and female undergraduate college students' is not accepted. This finding is in contrast with many of the studies conducted earlier, where they had found significant differences in the character strengths when gender was taken into consideration. Alex Linley and colleagues (2007) found that females scored higher than males on the strengths of love, kindness and social intelligence, and in the dimension of creativity males were found to score higher. The findings of the current study also stands in contrast with the results Miljković and Rijavec (2008) who found sex differences in strengths in a sample of college students.

The t-test results for the 24 character strengths show that there is no significant difference between Arts and Science students. Therefore, the hypothesis-"There will be a difference in the character strengths of Arts and Science undergraduate college students" is not accepted.

The Pearson correlation results indicated that significant correlation existed between the character strengths of Appreciation of Beauty and Excellence, Fairness, Forgiveness, Honesty, Humour, Kindness, Love of Learning and Humility with the academic achievement of the students. Therefore the hypothesis-'There will be an association between character strengths and academic achievements of undergraduate college students' is partially accepted. In this connection the study conducted by Lounsbury et al. (2009) where it was found that among the 24 character strengths, 16 of them were significantly positively correlated with the academic grades of the students, with higher magnitudes of correlation of Persistence, selfregulation ad love of learning, with academic grades.

Therefore, the findings of our study provide extensive support that character strengths do contribute in the enhancement of academic performance of college students. Since the college environment is a setting where the students are free from the oversight of their parents, and wherein if they get an opportunity to develop their strengths it can lead to enhancement in their life and well-being, it is quite expected that a number of character strengths assessed by the VIA were related to academic achievement. The detailed breakdown of our findings is shown in the following tables: 


\section{Table 1: 2×2 Design for Academic Achievements}

\begin{tabular}{lll} 
& Arts & Science \\
\hline Male & $\mathrm{N}=60$ & $\mathrm{~N}=60$ \\
& $\mathrm{M}=54.522$ & $\mathrm{M}=65.055$ \\
& $\mathrm{SD}=12.6263$ & $\mathrm{SD}=10.1039$ \\
\hline Female & $\mathrm{N}=60$ & $\mathrm{~N}=60$ \\
& $\mathrm{M}=57.507$ & $\mathrm{M}=63.213$ \\
& $\mathrm{SD}=12.4102$ & $\mathrm{SD}=13.5565$ \\
\hline
\end{tabular}

2X2 Factorial Design

Total $=240$

\section{Source: Computed by the Authors}

Table 2: ANOVA Test for Academic Achievements

\begin{tabular}{lllllll} 
& & $\begin{array}{l}\text { Sum of } \\
\text { Squares }\end{array}$ & df & Mean Square & $F$ & Sig. \\
\hline Academic & Between Groups & 4325.123 & 3 & 1441.708 & 9.623 & .000 \\
\cline { 2 - 6 } Achievements & Within Groups & 35358.997 & 236 & 149.826 & & \\
\cline { 2 - 6 } & Total & 39684.120 & 239 & & &
\end{tabular}

Source: Computed by the Authors

Table 3: 2×2 Design for Appreciation of Beauty and Excellence

\begin{tabular}{lll} 
& Arts & Science \\
\hline Male & $\mathrm{N}=60$ & $\mathrm{~N}=60$ \\
& $\mathrm{M}=3.944$ & $\mathrm{M}=4.094$ \\
& $\mathrm{SD}=.7791$ & $\mathrm{SD}=.6351$ \\
\hline Female & $\mathrm{N}=60$ & $\mathrm{~N}=60$ \\
& $\mathrm{M}=3.950$ & $\mathrm{M}=4.239$ \\
& $\mathrm{SD}=.5719$ & $\mathrm{SD}=.6527$ \\
\hline
\end{tabular}

2X2 Factorial Design $\quad$ Total $=240$

\section{Source: Computed by the Authors}

\section{Table 4: $2 \times 2$ Design for Bravery}

\begin{tabular}{lll} 
& Arts & Science \\
\hline Male & $\mathrm{N}=60$ & $\mathrm{~N}=60$ \\
& $\mathrm{M}=3.983$ & $\mathrm{M}=3.878$ \\
& $\mathrm{SD}=.6301$ & $\mathrm{SD}=.5981$ \\
\hline Female & $\mathrm{N}=60$ & $\mathrm{~N}=60$ \\
& $\mathrm{M}=3.889$ & $\mathrm{M}=4.100$ \\
& $\mathrm{SD}=.5811$ & $\mathrm{SD}=.5800$ \\
\hline 2X2 Factorial Design & Total=240 &
\end{tabular}

Source: Computed by the Authors 
Table 5: 2×2 Design for Love

\begin{tabular}{lll} 
& Arts & Science \\
\hline Male & $\mathrm{N}=60$ & $\mathrm{~N}=60$ \\
& $\mathrm{M}=3.961$ & $\mathrm{M}=3.756$ \\
& $\mathrm{SD}=.8789$ & $\mathrm{SD}=.7760$ \\
\hline Female & $\mathrm{N}=60$ & $\mathrm{~N}=60$ \\
& $\mathrm{M}=4.078$ & $\mathrm{M}=4.194$ \\
& $\mathrm{SD}=.6563$ & $\mathrm{SD}=.6474$ \\
\hline 2X2 Factorial Design & Total $=240$ &
\end{tabular}

\section{Source: Computed by the Authors}

\section{Table 6: 2×2 Design For Prudence}

\begin{tabular}{lll} 
& Arts & Science \\
\hline Male & $\mathrm{N}=60$ & $\mathrm{~N}=60$ \\
& $\mathrm{M}=3.667$ & $\mathrm{M}=3.544$ \\
& $\mathrm{SD}=.8592$ & $\mathrm{SD}=.7516$ \\
\hline Female & $\mathrm{N}=60$ & $\mathrm{~N}=60$ \\
& $\mathrm{M}=3.800$ & $\mathrm{M}=3.667$ \\
& $\mathrm{SD}=.7189$ & $\mathrm{SD}=.8302$ \\
\hline
\end{tabular}

2X2 Factorial Design

$$
\text { Total }=240
$$

\section{Source: Computed by the Authors}

\section{Table 7: $2 \times 2$ Design for Teamwork}

\begin{tabular}{lll} 
& Arts & Science \\
\hline Male & $\mathrm{N}=60$ & $\mathrm{~N}=60$ \\
& $\mathrm{M}=3.861$ & $\mathrm{M}=3.844$ \\
& $\mathrm{SD}=.5799$ & $\mathrm{SD}=.5573$ \\
\hline Female & $\mathrm{N}=60$ & $\mathrm{~N}=60$ \\
& $\mathrm{M}=3.911$ & $\mathrm{M}=4.133$ \\
& $\mathrm{SD}=.5553$ & $\mathrm{SD}=.5925$
\end{tabular}

2X2 Factorial Design

Total $=240$

\section{Source: Computed by the Authors}

Table 8: 2×2 Design for Creativity

\begin{tabular}{lll} 
& Arts & Science \\
\hline Male & $\mathrm{N}=60$ & $\mathrm{~N}=60$ \\
& $\mathrm{M}=3.522$ & $\mathrm{M}=3.656$ \\
& $\mathrm{SD}=.8534$ & $\mathrm{SD}=.6915$ \\
\hline Female & $\mathrm{N}=60$ & $\mathrm{~N}=60$ \\
& $\mathrm{M}=3.389$ & $\mathrm{M}=3.672$ \\
& $\mathrm{SD}=.6975$ & $\mathrm{SD}=.4929$ \\
\hline
\end{tabular}

2X2 Factorial Design

Total $=240$

\section{Source: Computed by the Authors}


Table 9: 2×2 Design for Curiosity

\begin{tabular}{lll} 
& Arts & Science \\
\hline Male & $\mathrm{N}=60$ & $\mathrm{~N}=60$ \\
& $\mathrm{M}=3.961$ & $\mathrm{M}=3.800$ \\
& $\mathrm{SD}=.5921$ & $\mathrm{SD}=.6019$ \\
\hline Female & $\mathrm{N}=60$ & $\mathrm{~N}=60$ \\
& $\mathrm{M}=3.883$ & $\mathrm{M}=3.783$ \\
& $\mathrm{SD}=.6576$ & $\mathrm{SD}=.6101$ \\
\hline
\end{tabular}

2X2 Factorial Design

Total $=240$

\section{Source: Computed by the Authors}

\section{Table 10: $2 \times 2$ Design for Fairness}

\begin{tabular}{lll} 
& Arts & Science \\
\hline Male & $\mathrm{N}=60$ & $\mathrm{~N}=60$ \\
& $\mathrm{M}=4.078$ & $\mathrm{M}=4.217$ \\
& $\mathrm{SD}=.6270$ & $\mathrm{SD}=.5719$ \\
\hline Female & $\mathrm{N}=60$ & $\mathrm{~N}=60$ \\
& $\mathrm{M}=4.194$ & $\mathrm{M}=4.511$ \\
& $\mathrm{SD}=.4882$ & $\mathrm{SD}=.4733$
\end{tabular}

2X2 Factorial Design Total $=240$

\section{Source: Computed by the Authors}

\section{TABLE 11: $2 \times 2$ Design for Forgiveness}

\begin{tabular}{lll} 
& Arts & Science \\
\hline Male & $\mathrm{N}=60$ & $\mathrm{~N}=60$ \\
& $\mathrm{M}=3.767$ & $\mathrm{M}=3.817$ \\
& $\mathrm{SD}=.7398$ & $\mathrm{SD}=.6873$ \\
\hline Female & $\mathrm{N}=60$ & $\mathrm{~N}=60$ \\
& $\mathrm{M}=3.822$ & $\mathrm{M}=4.056$ \\
& $\mathrm{SD}=.6450$ & $\mathrm{SD}=.6783$
\end{tabular}

2X2 Factorial Design

Total $=240$

\section{Source: Computed by the Authors}

\section{Table 12: 2×2 Design for Gratitude}

\begin{tabular}{lll} 
& Arts & Science \\
\hline Male & $\mathrm{N}=60$ & $\mathrm{~N}=60$ \\
& $\mathrm{M}=3.844$ & $\mathrm{M}=3.650$ \\
& $\mathrm{SD}=.6273$ & $\mathrm{SD}=.5705$ \\
\hline Female & $\mathrm{N}=60$ & $\mathrm{~N}=60$ \\
& $\mathrm{M}=3.839$ & $\mathrm{M}=4.011$ \\
& $\mathrm{SD}=.6213$ & $\mathrm{SD}=.5821$ \\
\hline
\end{tabular}

2X2 Factorial Design

Total $=240$ 
Table13: 2×2 Design for Honesty

\begin{tabular}{lll} 
& Arts & Science \\
\hline Male & $\mathrm{N}=60$ & $\mathrm{~N}=60$ \\
& $\mathrm{M}=3.917$ & $\mathrm{M}=4.106$ \\
& $\mathrm{SD}=.7121$ & $\mathrm{SD}=.5004$ \\
\hline Female & $\mathrm{N}=60$ & $\mathrm{~N}=60$ \\
& $\mathrm{M}=4.000$ & $\mathrm{M}=4.317$ \\
& $\mathrm{SD}=.5658$ & $\mathrm{SD}=.5900$ \\
\hline
\end{tabular}

2X2 Factorial Design

Total $=240$

\section{Source: Computed by the Authors}

\section{Table 14: 2×2 Design for Hope}

\begin{tabular}{lll} 
& Arts & Science \\
\hline Male & $\mathrm{N}=60$ & $\mathrm{~N}=60$ \\
& $\mathrm{M}=4.133$ & $\mathrm{M}=3.989$ \\
& $\mathrm{SD}=.6325$ & $\mathrm{SD}=.6228$ \\
\hline Female & $\mathrm{N}=60$ & $\mathrm{~N}=60$ \\
& $\mathrm{M}=4.056$ & $\mathrm{M}=4.111$ \\
& $\mathrm{SD}=.5730$ & $\mathrm{SD}=.6249$ \\
\hline
\end{tabular}

2X2 Factorial Design Total $=240$

\section{Source: Computed by the Authors}

\section{Table 15: 2×2 Design for Humour}

\begin{tabular}{lll} 
& Arts & Science \\
\hline Male & $\mathrm{N}=60$ & $\mathrm{~N}=60$ \\
& $\mathrm{M}=3.644$ & $\mathrm{M}=3.756$ \\
& $\mathrm{SD}=.7513$ & $\mathrm{SD}=.7180$ \\
\hline Female & $\mathrm{N}=60$ & $\mathrm{~N}=60$ \\
& $\mathrm{M}=3.611$ & $\mathrm{M}=3.583$ \\
& $\mathrm{SD}=.7214$ & $\mathrm{SD}=.6796$ \\
\hline
\end{tabular}

2X2 Factorial Design

Total $=240$

\section{Source: Computed by the Authors}

\section{Table 16: $2 \times 2$ Design for Perseverance}

\begin{tabular}{lll} 
& Arts & Science \\
\hline Male & $\mathrm{N}=60$ & $\mathrm{~N}=60$ \\
& $\mathrm{M}=3.828$ & $\mathrm{M}=3.789$ \\
& $\mathrm{SD}=.6792$ & $\mathrm{SD}=.7541$ \\
\hline Female & $\mathrm{N}=60$ & $\mathrm{~N}=60$ \\
& $\mathrm{M}=3.644$ & $\mathrm{M}=3.756$ \\
& $\mathrm{SD}=.7387$ & $\mathrm{SD}=.7463$
\end{tabular}


Table 17: $2 \times 2$ Design for Judgement

\begin{tabular}{lll} 
& Arts & Science \\
\hline Male & $\mathrm{N}=60$ & $\mathrm{~N}=60$ \\
& $\mathrm{M}=3.911$ & $\mathrm{M}=3.833$ \\
& $\mathrm{SD}=.5381$ & $\mathrm{SD}=.5262$ \\
\hline Female & $\mathrm{N}=60$ & $\mathrm{~N}=60$ \\
& $\mathrm{M}=3.800$ & $\mathrm{M}=4.022$ \\
& $\mathrm{SD}=.5698$ & $\mathrm{SD}=.6344$ \\
\hline
\end{tabular}

2X2 Factorial Design

Total $=240$

\section{Source: Computed by the Authors}

\section{Table18: $2 \times 2$ Design for Kindness}

\begin{tabular}{lll} 
& Arts & Science \\
\hline Male & $\mathrm{N}=60$ & $\mathrm{~N}=60$ \\
& $\mathrm{M}=4.139$ & $\mathrm{M}=4.283$ \\
& $\mathrm{SD}=.6703$ & $\mathrm{SD}=.4418$ \\
\hline Female & $\mathrm{N}=60$ & $\mathrm{~N}=60$ \\
& $\mathrm{M}=4.200$ & $\mathrm{M}=4.383$ \\
& $\mathrm{SD}=.6384$ & $\mathrm{SD}=.5344$
\end{tabular}

2X2 Factorial Design Total $=240$

\section{Source: Computed by the Authors}

Table 19: 2×2 Design for Leadership

\begin{tabular}{lll} 
& Arts & Science \\
\hline Male & $\mathrm{N}=60$ & $\mathrm{~N}=60$ \\
& $\mathrm{M}=4.072$ & $\mathrm{M}=4.028$ \\
& $\mathrm{SD}=.5628$ & $\mathrm{SD}=.6445$ \\
\hline Female & $\mathrm{N}=60$ & $\mathrm{~N}=60$ \\
& $\mathrm{M}=3.811$ & $\mathrm{M}=4.183$ \\
& $\mathrm{SD}=.6534$ & $\mathrm{SD}=.5400$
\end{tabular}

2X2 Factorial Design

Total $=240$

\section{Source: Computed by the Authors}

\section{Table 20: $2 \times 2$ Design for Love of Learning}

\begin{tabular}{lll} 
& Arts & Science \\
\hline Male & $\mathrm{N}=60$ & $\mathrm{~N}=60$ \\
& $\mathrm{M}=3.283$ & $\mathrm{M}=3.217$ \\
& $\mathrm{SD}=.7020$ & $\mathrm{SD}=.7927$ \\
\hline Female & $\mathrm{N}=60$ & $\mathrm{~N}=60$ \\
& $\mathrm{M}=3.111$ & $\mathrm{M}=3.378$ \\
& $\mathrm{SD}=.5614$ & $\mathrm{SD}=.7478$
\end{tabular}

\section{Source: Computed by the Authors}


Table 21: 2×2 Design for Humility

\begin{tabular}{lll} 
& Arts & Science \\
\hline Male & $\mathrm{N}=60$ & $\mathrm{~N}=60$ \\
& $\mathrm{M}=3.567$ & $\mathrm{M}=3.356$ \\
& $\mathrm{SD}=.5960$ & $\mathrm{SD}=.6719$ \\
\hline Female & $\mathrm{N}=60$ & $\mathrm{~N}=60$ \\
& $\mathrm{M}=3.572$ & $\mathrm{M}=3.722$ \\
& $\mathrm{SD}=.6697$ & $\mathrm{SD}=.7496$ \\
\hline
\end{tabular}

2X2 Factorial Design

Total $=240$

\section{Source: Computed by the Authors}

Table22: 2×2 Design for Perspective

\begin{tabular}{lll} 
& Arts & Science \\
\hline Male & $\mathrm{N}=60$ & $\mathrm{~N}=60$ \\
& $\mathrm{M}=3.528$ & $\mathrm{M}=3.528$ \\
& $\mathrm{SD}=.7890$ & $\mathrm{SD}=.6870$ \\
\hline Female & $\mathrm{N}=60$ & $\mathrm{~N}=60$ \\
& $\mathrm{M}=3.350$ & $\mathrm{M}=3.539$ \\
& $\mathrm{SD}=.7452$ & $\mathrm{SD}=.6201$ \\
\hline
\end{tabular}

2X2 Factorial Design Total $=240$

\section{Source: Computed by the Authors}

Table 23: 2×2 Design for Self-Regulation

\begin{tabular}{lll} 
& Arts & Science \\
\hline Male & $\mathrm{N}=60$ & $\mathrm{~N}=60$ \\
& $\mathrm{M}=3.011$ & $\mathrm{M}=3.033$ \\
& $\mathrm{SD}=.7156$ & $\mathrm{SD}=.8386$ \\
\hline Female & $\mathrm{N}=60$ & $\mathrm{~N}=60$ \\
& $\mathrm{M}=3.006$ & $\mathrm{M}=2.850$ \\
& $\mathrm{SD}=.6538$ & $\mathrm{SD}=.7116$
\end{tabular}

2X2 Factorial Design Total $=240$

\section{Source: Computed by the Authors}

Table 24: 2×2 Design for Social Intelligence

\begin{tabular}{lll} 
& Arts & Science \\
\hline Male & $\mathrm{N}=60$ & $\mathrm{~N}=60$ \\
& $\mathrm{M}=4.000$ & $\mathrm{M}=3.739$ \\
& $\mathrm{SD}=.6581$ & $\mathrm{SD}=.6891$ \\
\hline Female & $\mathrm{N}=60$ & $\mathrm{~N}=60$ \\
& $\mathrm{M}=3.822$ & $\mathrm{M}=3.817$ \\
& $\mathrm{SD}=.7010$ & $\mathrm{SD}=.7036$
\end{tabular}


Table 25: 2×2 Design for Spirituality

\begin{tabular}{lll} 
& Arts & Science \\
\hline Male & $\mathrm{N}=60$ & $\mathrm{~N}=60$ \\
& $\mathrm{M}=3.939$ & $\mathrm{M}=3.600$ \\
& $\mathrm{SD}=.6652$ & $\mathrm{SD}=.7486$ \\
\hline Female & $\mathrm{N}=60$ & $\mathrm{~N}=60$ \\
& $\mathrm{M}=4.039$ & $\mathrm{M}=3.828$ \\
& $\mathrm{SD}=.5561$ & $\mathrm{SD}=.5966$ \\
\hline
\end{tabular}

2X2 Factorial Design

Total $=240$

\section{Source: Computed by the Authors}

Table 26: $2 \times 2$ Design for Zest

\begin{tabular}{lll} 
& Arts & Science \\
\hline Male & $\mathrm{N}=60$ & $\mathrm{~N}=60$ \\
& $\mathrm{M}=3.794$ & $\mathrm{M}=3.756$ \\
& $\mathrm{SD}=.7618$ & $\mathrm{SD}=.6858$ \\
\hline Female & $\mathrm{N}=60$ & $\mathrm{~N}=60$ \\
& $\mathrm{M}=3.878$ & $\mathrm{M}=3.872$ \\
& $\mathrm{SD}=0.5657$ & $\mathrm{SD}=0.6498$ \\
\hline
\end{tabular}

2X2 Factorial Design Total $=240$

\section{Source: Computed by the Authors}

Table 27: T-test Analysis for Male and Female Undergraduate Students on Academic Achievements and Character Strengths

\begin{tabular}{lllll} 
Variables & Male & Female & t-ratio & Significance \\
\hline Academic & $M=59.788$ & $M=60.360$ & 0.343 & 0.732 \\
Achievements & $S D=12.5550$ & $S D=13.2547$ & & (Not significant) \\
\hline Character Strengths & $M=3.792$ & $M=3.829$ & 0.4178 & 0.6781 \\
& $S D=0.275$ & $S D=0.343$ & & (Not significant)
\end{tabular}

Source: Computed by the Authors

Table 28: T-test Analysis for Arts and Science Undergraduate Students on Academic Achievements and Character Strengths

\begin{tabular}{|c|c|c|c|c|}
\hline Variables & Arts & Science & t-ratio & Significance \\
\hline Academic & $M=56.014$ & $M=64.134$ & 5.134 & .000 \\
\hline Achievements & $S D=12.5558$ & $S D=11.9410$ & & (Significant) \\
\hline Character Strengths & $\begin{array}{l}M=3.783 \\
S D=0.285\end{array}$ & $\begin{array}{l}M=3.833 \\
S D=0.332\end{array}$ & 0.5596 & $\begin{array}{l}0.5785 \\
\text { (Not significant) }\end{array}$ \\
\hline
\end{tabular}

Source: Computed by the Authors 
After meticulous analysis of all the tables, it has been found in Table 2 that in the case of academic achievements, a significant difference between the means of the different groups was found. In other words, a significant difference between the means of the groups was found when streams and gender were taken together.

Similarly, from Table 27, we can see that after conducting the t-test, no significant difference between the means of male and female students were found when character strengths was taken into consideration. In the same way, the Table 28 shows that there is no significant difference in the character strengths of the students between the arts and science streams.

\section{Conclusion}

The key purpose of the present research was to find the existence of character strengths across male and female undergraduate college students and to find out if any relationship exists between the strengths of character and academic achievement of the students. Therefore, it can be concluded that, character strengths do play an important role in influencing the academic achievement of students in the college level. After carrying out the ANOVA and t-test, it was found that no significant difference existed in the context of character strengths, between both male and female, as well as arts and science undergraduate students. In addition, it was found that academic achievement of the science stream students was significantly higher as compared to the students of the arts stream. The probable reason for this significant difference could be because a few subjects in the science stream are comparatively more scoring and are more objective-based as compared to the subjects of the arts stream, which are more of subjective. The following section deals with the limitations of the current study, and emphasises on a number of suggestions, based on the observations made during the study.

\section{Limitations}

Although the current study was conducted taking into consideration the ethics, the necessary research conditions and a detailed study, but it is not free from limitations.

- Firstly, the sample size was comparatively small, so when generalizing the results, caution has to be taken. The results obtained so far cannot be generalized in the context of all the undergraduate colleges of Guwahati city, and therefore the sample size can be increased in order to obtain more accurate results in future researches.

- Secondly, the period allotted for the process of data collection was relatively less, which influenced the rapport development of the researcher with the participants.

- The respondents in the beginning had difficulty in understanding the meaning of a few questions, as a number of them were from vernacular medium; therefore, the researcher had to translate each statement in the questionnaire for the ease of understanding of the respondents. The questions in the VIA questionnaire was not translated into Assamese, which is the local language of Assam, because many of the positive psychology terms used in the questionnaire, would not convey the same message when translated to Assamese, and, therefore, the purpose using the VIA-IS to assess the true character strengths of the students might not have been met. Extraneous variables, such as lethargy, noise from the adjacent playgrounds and corridors, and room temperature also at times seemed to influence the tendency of responding honestly on the part of the participants

- The questionnaire used was close ended, and therefore the students could not give detailed responses about their feelings. 


\section{Recommendations}

- Training programmes emphasising on the development of character strengths should be implemented in the colleges

- Teachers and administrators should be trained in understanding and identifying and focusing on the strengths and positive aspects of the students rather than only on the weaknesses

- There should be introduction of activities and assignments that would require more of critical and creative thinking on the part of the students.

- Also more in-depth qualitative data can be obtained when measuring such important dimensions such as character strengths are concerned and the questionnaires used can be open ended rather than only being close-ended ones.

\section{References}

Allan, B. A., \& Duffy, R. D. (2014). Examining Moderators of Signature Strengths Use and Well-being: Calling and Signature Strengths Level. Journal of Happiness Studies, 15(2), 323337. doi: 10.1007/s10902-013-9424-0

Brdar, I., Anić, P., \& Rijavec, M. (2010). Character Strengths and Well-Being: Are there Gender Differences?. In: Brdar, I. (ed.), The Human Pursuit of Well-Being: A Cultural Approach. Dordrecht, NL: Springer, pp. 145156. DOI: 10.1007/978-94-007-1375-8_13

Chung, H. (2008). Resiliency and Character Strengths among College Students. Phd dissertation, The University of Arizona, Graduate College. Retrieved from http://hdl.handle.net/10150/195507

Froh, J. J. (May/June 2004). The History of Positive Psychology: Truth Be Told. NYS Psychologist, 18-20.

Govindji, R., \& Linley, P. A. (2007). Strengths Use, Self-concordance and Well-being: Implication for Strengths Coaching and Coaching Psychologist. International Coaching Psychology Review, 2, 143-153.
Gustems, J., \& Calderon, C. (2014). Character Strengths and Psychological Wellbeing among Students of Teacher Education. International Journal of Educational Psychology, 3(3), 265286.doi: 10.4471/ijep.2014.14

Hussain, L., Khan, A. N., Latif, M., Amin, I., \& Sibatin, M. (April 2011). Comparative Study of Academic Achievement of Science and Arts Student in Compulsory Subject at Secondary School Level. Interdisciplinary Journal of Contemporary Research in Business, 2(12), 752.

Ianni, P. A. (2012). Does Frequent Use of Signature Strengths Enhance Academic WellBeing? Electronic Theses and Dissertations, Paper 4816.

Linley, A., Maltby, J., Wood, A. M., Joseph, S., Harrington, S., Peterson, C., \& Seligman, M. E. P. (2007). Character Strengths in the United Kingdom: The VIA Inventory of Strengths. Personality and Individual Differences, 43, 341-351. doi: http://dx.doi.org/10.1016/j.paid.2006.12.004

Linley, P., Nielsen, K. M., Gillett, R., \& BiswasDiener, R. (2010). Using Signature Strengths in Pursuit of Goals: Effects on Goal Progress, Need Satisfaction, and Well-being, and Implications for Coaching Psychologists. International Coaching Psychology Review, 5(1), 6-15.

Lounsbury, J. W., Fisher, L. A., Levy, J, \& Welsh, D. P., (2009). An Investigation of Character Strengths in Relation to the Academic Success of College Students. Individual Differences Research, Vol. 7, No. 1, ISSN: 1541-745X, pp. 52-69.

Miljković, D, \& Rijavec, M., (2008). What Makes Us Happy: Strengths of Mind, Strengths of Heart, or Self-control? In M. Cindrić, V. Domović, Y M. Matijević (eds.). Pedagogy and the Knowledge Society (pp. 241-250).Zagreb: Učiteljskifakultet.

Park, N., Peterson, C., \& Seligman, M. E. P., (2004). Strengths of Character and Well-Being. Journal of Social and Clinical Psychology, Vol. 23, No. 5, pp. 603-619.

Peterson, C., \& Seligman, M. E. P., (2003). Values in Action (VIA) Classification of 
Strengths. American Psychological Association, 2003.

Peterson, C., \& Seligman, M. E. P., (2004). Character Strengths and Virtues: A Handbook and Classification. Washington, DC: American Psychological Association.

Proctor, C., Tsukayama, E., Wood, A. M., Maltby, J., Eades, J., \& Linley, P., (2011). Strengths Gym: The Impact of a Character Strengths-based Intervention on the Life Satisfaction and Well-being of Adolescents. The Journal of Positive Psychology, 6(5), 377-388. doi:10.1080/17439760.2011.594079.

Seligman, M. E. P., \& Csikszentmihalyi, M. (eds) (2000). Positive Psychology [Special issue] American Psychologist, 55 (1).

Seligmann, M. E. P. (2002). Authentic Happiness: Using the New Positive Psychology to Realize your Potential for Lasting Fulfillment. New York, NY: Free Press.

Seligman, M. E. P., Steen, T. A., Park, N., \& Peterson, C. (2005). Positive Psychology Progress: Empirical Validation of Interventions. American Psychologist, 60(5), 410-421. doi:10.1037/0003066X.60.5.410.

Snyder, C. R. \& Lopez, S. (2007). Positive Psychology: The Scientific and Practical Explorations of Human Strengths. Thousand Oaks, CA: SAGE Publications.

Shryack, J., Steger, M. F., Krueger, R. F., \& Kallie, C. S. (2010). The Structure of Virtue: An Empirical Investigation of the Dimensionality of the Virtues in Action Inventory of Strengths, Personality and Individual Differences, pg. 48, (2010), 714-719.

Singh, K., \& Choubisa, R. (2010). Empirical Validation of Values in Action-inventory of Strengths (VIA-IS) in Indian Context. Psychological Studies, Vol. 55, Issue 2, pp 151158, DOI: 10.1007/s12646-010-0015-4.

Singh, K., \& Sharma, S. (2015). Self-Perception, Character Strengths and Happiness Factors among North Indian Adolescents. The International Journal of Indian Psychology, ISSN
2348-5396 (e) | ISSN: 2349-3429 (p), Vol. 3, Issue 1, No.6, DIP: C03109V3I12015, October December, 2015, pp. 168-180. Retrieved from http://oaji.net/articles/2015/1170-

1447429047.pdf

Sin, L. N., \& Lyubomirsky, S. (2009). Enhancing Well-Being and Alleviating Depressive Symptoms with Positive Psychology Interventions: A Practice-Friendly MetaAnalysis. Journal of Clinical Psychology: In Session, Vol. 65(5), 467-487 (2009), DOI: 10.1002/jclp.20593

Snyder, C. R., Lopez, S. J., \& Pedrotti, J. T. (2010). Positive Psychology: The Scientific and Practical Explorations of Human Strengths, $2^{\text {nd }}$ Edition. SAGE Publications.

Sze, D. (2015). The Father of Positive Psychology and His Two Theories of Happiness, The Huffington Post, August 2015. Retrieved from

http://www.huffingtonpost.com/entry/thefather-of-positive-

ps_b_7600226.html?section=india

The VIA Institute on Character. Frequently Asked Questions. Retrieved from https://www.viacharacter.org/www/AboutIns titute/FAQs?QuestionID=37\&AFMID $=592$

The VIA Institute on Character. Character: $A$ Deep Dive. Retrieved from http://www.viacharacter.org/www/CharacterStrengths/Character

The VIA Institute on Character. The VIA Classification of Character Strengths. Retrieved from,

http://www.viacharacter.org/www/Portals/0/C lassification\%202014.pdf

Tripathi, R., Banu, H., \& Mehrotra, S. (2015). Self-perceived Character Strengths in Urban Indian Youth: Observations and Reflections, Journal of the Indian Academy of Applied Psychology, Vol. 41, No.3 (Special Issue), 175186. Retrieved from http://jiaap.org/Listing_Detail/Logo/347dOfc0482c-4c79-8ae8-11d312c88acd.pdf 